\title{
Rough Justice: Inside the British Asylum System
}

\author{
Harvey Burgess
}

\begin{abstract}
This paper constitutes a detailed analysis and critique of the British asylum system from 1997 until the present day. It covers all the clearly defined areas of government policy, including funding, detention, deportation, human rights, European Union obligations, and asylum welfare. It also addresses the role of the judiciary and cites many of the landmark legal cases that have had a major impact on the sector. In providing a comprehensive overview of asylum and immigration that spans the entire period of the Labour government and the first few months of the new Coalition's tenure, the author aims to show that an often illiberal UK asylum policy is largely governed by principles of deterrent and political expediency. Only an enlightened House of Lords, now the Supreme Court, has served as a bulwark for justice and mitigated the effect of draconian government policies.
\end{abstract}

\section{Résumé}

Cet article est une analyse détaillée et une critique du système de l'asile britannique de 1997 à aujourd'hui. Il couvre tous les domaines clairement définis de la politique gouvernementale, dont le financement, la détention, la déportation, les droits de la personne, les obligations en vertu de l'Union européenne et l'aide sociale offerte aux demandeurs d'asile. Il s'attarde aussi sur le rôle de la justice et cite des cas ayant fait jurisprudence qui ont eu d'importantes répercussions. En fournissant un portrait complet de la situation de l'asile et de l'immigration durant toute la durée du gouvernement travailliste et les premiers mois du mandat de la nouvelle coalition, l'auteur cherche à montrer que la politique restrictive en matière d'asile au R.-U. est largement régie par des principes de dissuasion et d'opportunisme politique. Seule une Chambre des lords éclairée et aujourd'hui la Cour suprême ont servi de rempart pour la justice et ont atténué les effets des politiques draconiennes du gouvernement.

About suffering they were never wrong, The Old Masters: how well they understood its human position; how it takes place while someone else is eating or opening a window or just walking dully along. ${ }^{1}$

\section{Introduction}

This paper constitutes a comprehensive analysis of the British asylum sector between 1997, the year that the Labour Party acceded to office after eighteen years of Conservative rule, and the present day. It aims to present a balanced critique of government policy from a practitioner's perspective. Issues such as legal aid funding, the role of the judiciary, detention, deportation, human rights policy, welfare, and British participation in European Union immigration policies are all addressed in detail. I shall endeavour to show that UK asylum policy is often illiberal and largely governed by principles of deterrent and political expediency.

\section{Legal Aid and the Demise of Two of the Major Publicly Funded Refugee Charities}

On 16 June 2010, the UK's new Conservative-Liberal Democrat coalition government presided over the demise of one of the longest standing and most respected national refugee charities. Refugee and Migrant Justice (RMJ), formerly the Refugee Legal Centre, which had provided free advice and representation for vulnerable asylum seekers since it was founded in 1992, went into administration.

In 2005, it was given a human rights award from the human rights campaigning organizations, Liberty and Justice and the Law Society, for "consistent and fearless use of the law to protect human rights and hold immigration and asylum policies up to the scrutiny of the courts." 
RMJ had been a shining beacon within the sector and its demise heralded a new low for legal aid immigration and asylum practitioners, as well as its 10,000 asylum-seeking clients who suddenly found themselves without legal representation.

The RMJ was no longer able to remain solvent due to a change of policy introduced by the then Labour government which prevented it from billing its work in progress while cases were still ongoing. Given that cases can continue for several years, it has never been viable for organizations reliant upon legal aid to function without staged billing. The Justice Secretary in the new coalition government, Ken Clarke, claimed that the RMJ failed to make the efficiency savings of other immigration providers. The RMJ rejected that allegation, arguing that it worked a minor miracle by continuing to operate for years in the face of swinging cuts in its budget, particularly the replacement of hourly rates by the fixed fee system.

On 11 July 2011, the Immigration Advisory Service (IAS), the largest provider of publicly funded asylum and immigration legal advice and representation, went into administration. The IAS had been in existence for thirty-five years and employed 300 people. It routinely handled over 20,000 cases a year. The government's decision to remove immigration from the scope of legal aid and also to reduce the legal aid fees for refugees seeking asylum in the UK by 10 per cent, resulted in the IAS losing 60 per cent of its income.

The Legal Services Commission (LSC), which had raised concerns over the IAS's financial management, stated that the decision taken by the IAS to go into administration was "theirs alone."

Practitioners would adduce the sad end of both the RMJ and the IAS as evidence that the government is seeking both to undermine immigration and asylum practitioners and to restrict access to justice for their clients.

The LSC, formerly the Legal Aid Board, is the agency mandated to administer legal aid, a system predicated upon access to justice for the unemployed and lowest income segments of society. In the early years of the New Labour period, the LSC encouraged dynamic small and medium sized immigration firms to expand, but it signally failed to follow through on its commitment to good quality immigration and asylum representation. Instead, increasingly lent on by government, it set about cutting costs and increasing bureaucracy with gusto. One by one, respected, longstanding legal aid immigration lawyers either were forced out of business altogether or decided to move into the private sector.

Multi-million pound "super" contracts were negotiated with a handful of large firms, the vast majority of which were known within the sector to be disreputable. Prime
Minister Blair and a succession of hard-line home secretaries, notably David Blunkett and Jack Straw, launched stinging attacks on human rights lawyers, whom they alleged were cynically milking the system by stringing out cases and bringing frivolous appeals. Many practitioners were of the opinion that New Labour did not want to be inconvenienced by conscientious asylum lawyers who were not prepared to allow poor decision making to go unchallenged. Its ultimate aim appeared to be a pared down, American-style system of public defenders.

For at least half a decade under New Labour, the Home Office became a nightmare to deal with. It was supposed to be undergoing a complete overhaul, to include a new computer system costing an estimated 80 million pounds, which was eventually scrapped in 2001. Hundreds of files were lost and getting through on the telephone was virtually impossible. With the exception of minors, Legal Aid for representatives to attend their clients' asylum interviews was discontinued.

\section{New Labour's Asylum Policy}

In 1998, a year after Labour came into office, they tagged their new policy on immigration and asylum "Fairer, Faster and Firmer." The "Fairer" element of the package consisted of warm words as to the contribution made by immigrants to British society, an amnesty for 10,000 asylum seekers who had been waiting for a decision since 1993 (a backlog of 50,000 undecided applications had accrued), and the right of detainees to have automatic bail hearings. However, it soon became clear that government policy would be largely influenced by the Europe-wide push to harmonize asylum and immigration policy. Governments across Europe appeared to be at one in their desire to cut costs and ramp up controls.

The following measures all appeared in the government's 1999 asylum and immigration law: increased powers of enforcement and detention (including the continued detention of torture victims and children); the expansion of "fasttrack" appeals and a reduction in appeal rights, not least the right to appeal against deportation and to pursue Judicial Review actions in cases where a person faced removal on safe third country grounds; the termination of all welfare benefits to asylum seekers; and a new system of dispersal under which asylum seekers would be given no say as to where in the country they were sent. The offer of housing was to be made on a "take it or leave it" basis.

The pressing issue of the poor quality of initial decision making, a corollary of the culture of disbelief which permeated the whole system, was not addressed. The UK Home Office has long been infamous for its "cut and paste" refusal letters and the fact that it routinely refuses 95 per cent of 
applications. Historically, some 25 per cent of applicants have been successful in overturning those decisions in the immigration courts.

Judicial Review applications were knocked back by High Court judges with ever increasing regularity and Immigration judges showed no compunction in rubbishing expert reports and either ignoring or quoting selectively from human rights reports.

In October 2000, the European Convention on Human Rights (ECHR) was enshrined into British law by way of the Human Rights Act (HRA), a development that received a widespread welcome. The aim was to protect the individual from public authorities that violated Convention rights and to bring human rights issues within domestic jurisdiction. In order to dampen down any premature optimism that New Labour intended to be a pioneer in the cause of human rights, the Home Office minister, Mike O’Brien, immediately declared that the legislation should be viewed as "a shield, not a sword for rights... ."

As far as asylum was concerned, the advent of the HRA impacted most of all on Articles 3-the right not to be subjected to inhuman and degrading treatment-and 8 - the right to a private and family life-of the ECHR. Applicants had previously had to rely on Home Office discretionary policies which did not generate appeal rights so the formalization of such rights was unreservedly beneficial. The HRA provided a valuable benchmark as to the interpretation of humanitarian law. Minds were certainly focused and the ECHR dovetailed nicely with the 1951 Refugee Convention.

\section{Post 9/11 Backlash: Deportation}

Within a year, 9/11 happened and the entire climate surrounding human rights was transformed. In the ensuing years, unprecedented anti-terrorism legislation was introduced. A new court entitled the Special Immigration Appeals Commission (SIAC) was set up to deal with the appeals of those facing deportation in relation to issues of terrorism and national security. Secret evidence was to be permitted and appellants could only be represented by special advocates who had to be vetted by the security services. Furthermore, punitive "control orders" (which involve electronically tagging the persons in question and placing a whole array of restrictions on who they can meet or speak to, where they can and cannot go or work, and what technology they can use) were introduced and the legal period of detention without charge was extended from forty-eight hours at the beginning of the decade to forty-two days by 2008. Predictably, the immigration and asylum sector felt the backlash, not least at the hands of a biased British press. Attacks on asylum seekers in the tabloids multiplied.
Emboldened by government policy and rhetoric, there was no limit to their vindictiveness and mendacity. Richard Desmond took the lead when he pledged to run a sustained campaign against asylum seekers in his newspaper, the Daily Express. During a single thirty-one day period in 2003, he ran twenty-two negative front-page stories on asylum seekers. Characterized by racism, homophobia, and xenophobia, the tabloids never passed up an opportunity to label asylum seekers as terrorists, criminals, and rapists. They were all illegal, bogus, and disease ridden as well as being responsible for the spread of HIV-AIDS in the UK, plotting to kill Tony Blair, and eating swans and donkeys!

The 2006 foreign prisoner scandal was the catalyst for a push by the government to deport foreign nationals en masse. For in April 2006 it came to light that over one thousand foreign prisoners had been freed even though the authorities had failed to consider whether or not they should face deportation proceedings. The Home Secretary admitted that he did not know where they all were and, given that some of them were drug dealers and sex offenders, the inevitable storm in the tabloid press followed. Equally predictably, the government tried to rectify its error by being as tough as possible. It introduced a new policy predicated upon a presumption that foreign prisoners would be deported at the end of their sentences and it also introduced plans for a compulsory biometric identification for all foreign nationals.

Historically, the immigration rules had provided for deportation action to be initiated if the crime committed carried a two-year custodial sentence. This was halved to one year in 2007. The Home Office began trawling through their records to find any foreign nationals with criminal records, regardless of how long ago the offence took place or how minor it may have been. Many hundreds of deportation orders were issued and families suffered as their loved ones were detained and informed that they were to be expelled (the case of Jimmy Mubenga, see below, illustrates how human rights law cannot always act as a safeguard for individuals who appear, prima facie, to have very strong cases).

The government then went even further in legislating to replace the presumption in favour of deportation with automatic deportation. As of August 2008, deportation was deemed unequivocally to be conducive to the public good. One example of the highly political nature of the issue is evidenced by the fact that there is a lay member alongside two judges at deportation hearings and he or she will often be interventionist in putting forward public opinion.

\section{Detention Policy}

The UK policy on detention of asylum seekers has long been controversial. In 1994, Amnesty International found that 
it breached international human rights standards, due to the fact that detainees were not being properly informed of the reasons for their detention, that there was no automatic scrutiny by a court of the decision to detain, and that they were often held in prisons alongside convicted prisoners.

The Home Office argues that it detains asylum seekers only as a last resort and only if it is thought that the risk of their absconding is high. The reality is that many of the one thousand or so asylum seekers who are locked up at any one time are detained upon arrival (often for the first time in their lives), and the statistics show that less than 4 per cent of those granted temporary admission into the UK abscond.

Article 31 of the 1951 Refugee Convention states that refugees should not be penalized for entering a country illegally. And yet, the UK has persisted in criminalizing those who enter the country with no documents or false documents or who are found to have destroyed their travel documents on the advice of their agent or smuggler. It is entirely arbitrary whom the Home Office decides to charge. There are around 5 per cent of new arrivals who are unlucky enough to be singled out and their sentences are usually 6 months or so. Even if the term does not reach the twelve-month threshold judges periodically recommend deportation.

Throughout the last two decades, there have been periodic disturbances at immigration detention centres, including hunger strikes and suicides. Campsfield House, an institution situated in the Oxfordshire countryside, which is run by Group 4 Security, was once referred to in the Financial Times as "part Franz Kafka, part George Orwell." It was the scene of two serious incidents, in 1994 and 1997, during which protests turned violent and had to be suppressed by riot police. Detainees complained of a lack of medical care, a loud and intrusive public address system, surveillance cameras everywhere, mail tampering, being transferred to prisons without their lawyers being informed, poor food, and inadequate recreational facilities.

Yarl's Wood immigration detention centre in Bedfordshire, a major removal centre for women and families, has had a history of unrest since it opened in 2001. It was devastated by fire in 2002 following a riot; in 2004, a report by the Prisons and Probations Ombudsman exposed staff racism and violence; in 2009, it was revealed that children were being denied urgent medical treatment; and in February 2010, an investigation was launched by Members of Parliament following allegations that women detainees were badly beaten up by employees of Serco, the private security firm which runs the centre, during an ongoing hunger strike.

Over the last fifteen years, I personally have sat opposite at least twenty clients in detention who have complained that they have been both physically and verbally abused by immigration officers or private security staff. Those who have been the subject of forced removal attempts have been particularly prone to violent treatment. My clients have described being restrained and beaten by as many as ten officials as they were bundled onto commercial airliners whilst they fought tooth and nail to resist removal.

As I write this, the story of the death of Jimmy Mubenga, a forty-six-year-old Angolan, on a British Airways plane stationed on the runway at Heathrow Airport, is front-page news. He was allegedly restrained by three security guards who handcuffed him and used excessive force. They were pressing down on him for at least forty-five minutes. One passenger across the aisle is quoted as saying that Mubenga complained of not being able to breathe for at least ten minutes before he lost consciousness and another has said that he was screaming at the back of the plane and repeatedly saying: "They're going to kill me."4 And that is exactly what they did. Mubenga never regained consciousness. He was taken to hospital and pronounced dead. The three security guards, who work for G4S, formerly referred to as Group 4 Security, were arrested but released on bail without being charged. Scotland Yard has said that the death is being treated as "unexplained."

A leaked G4S document has revealed that their staff are employing control and restraint techniques that the government's own advice warns can cause skull fractures, blindness, and asphyxia. ${ }^{5}$ Deportee escort has become a lucrative business for private security firms. G4S is estimated to have been paid more than 9 million pounds between May 2005 and November 2006 for this alone. ${ }^{6}$

Mubenga had been living in the UK for sixteen years. Originally an asylum seeker, he was initially granted Exceptional Leave to Remain (ELR), a limited but renewable status which leads to Indefinite Leave to Remain (ILR). He was a devoted family man with a wife and five childrentwo of whom were born in the UK-between the ages of sixteen years and seven months. In 2006, following a nightclub brawl, he was convicted of actual bodily harm and sentenced to two years in prison. The Home Office duly sought to deport him. He fought the case tooth and nail. His lawyer tells me that they were knocked back several times, both in the domestic courts and in the European Court which did not consider his case to be exceptional enough. By that time, Mubenga had ILR in the UK and the rest of his family, who had ELR, had applied for ILR at the end of their allotted period of ELR. For four years the Home Office apparently neglected to deal with their case, which ought to have been an academic exercise in granting them Leave in Line. The lawyer believes their motivation was clearly to weaken the Article 8 claim as it would have been harder to argue that 
the family could relocate to Angola if they were all settled in the UK.

Immigration enforcement officers invariably turn up en masse at their target's abode, at dawn on a weekend morning, knowing full well that the person's lawyer will usually not be working at that time. The experience of my Cameroonian client, Georges, is fairly typical. On his behalf, we had lodged an application for Judicial Review at the High Court. Whilst we were awaiting a response, his house was raided by at least eight armed immigration officers at 5.30 a.m. on a Sunday morning. Georges was held in a cell at Waterloo Station for twenty-four hours before being released. As so often happens, there had been a breakdown of communication either between government lawyers and the Immigration Service or between the senior immigration officers and their enforcement team, who were unaware that legal proceedings were pending and that Georges was not therefore removable from the UK. It was a clear case of unlawful detention and we referred the case to a lawyer specializing in that field. It took a long time but Georges was eventually compensated to the tune of 3,000 pounds. There are many instances of both unlawful detention and unlawful removal from the UK. (The Home Office periodically agrees to bring back erroneously returned individuals. In August 2010, it paid out 100,000 pounds in damages to a gay asylum seeker who was deported to his native Uganda where he was burned and hung upside down in prison.) Georges could easily have been put on a train to France, from where he had originally arrived, or even a plane to Cameroon, on that Sunday.

Right at the start of its tenure, in the summer of 2010, the coalition government pledged to end the detention of immigrant children, an unreservedly positive development. And yet, there are now fears that it is going to water down this commitment by setting up new centres to detain families who refuse to leave the country.

Expanding the number of failed asylum seekers who are detained is seen by governments of all persuasions as a useful tool for increasing the number of removals. The alleged failure of successive governments to remove enough failed asylum seekers has long been a hotly debated issue. New Labour was continually criticized by the Tories for having a poor record in that regard. It set itself a target of 30,000 removals a year but failed to get close to that figure, although, in 2006, it managed over 18,000.

Detention also impacts negatively on the ability of lawyers to represent their clients effectively, principally due to the strict deadlines for the preparation of cases. For example, in 2003, a fast-track system was introduced at Harmondsworth Immigration Removals Centre, close to Heathrow Airport (it was subsequently expanded to other centres). Single, male asylum seekers, whose cases, the authorities deemed, could be determined quickly were to be detained upon arrival and remain incarcerated throughout the procedure, until they were either removed or allowed to remain in the UK. The timescales were iniquitous. Asylum interviews took place on the day after arrival in the detention centre, decisions the following day, and appeals within a week of the refusal.

A 2006 report undertaken by Bail For Immigration Detainees (BID), showed that 99 per cent of the applications were refused and less than 3 per cent of appeals were successful. In 60 per cent of the cases reviewed by BID the Appellant had no legal representative in court whilst the Home Office was represented. There was a consensus that the system was set up to refuse applications as there was not enough time for detainees' cases to be prepared, nor was there enough time for bail applications to be made. In my experience, it is logistically impossible to assemble all the documents required, whether they are the client's personal documents, or press and human rights reports, or expert reports, in particular medico-legal reports, and also to have them translated into English where appropriate, within seven days.

The system of bail in the UK is signally lacking in settled procedures and structure. There are no practice directions (notes made by judges as to how specific procedures or formalities should be carried out) on bail nor are there any higher court judgments due to the fact that appeals are routinely predicated on the principle of habeas corpus (the right of every prisoner to challenge the terms of his or her incarceration in court before a judge) rather than on the specifics of a decision or procedural irregularities. Bail summaries, along with Entry Clearance refusal letters, have a reputation amongst lawyers as being particularly poorly reasoned.

\section{Human Rights: Articles 3 and 8 of the ECHR}

The House of Lords in the landmark case of Razgar ${ }^{7}$ set down the questions that need to be addressed when determining an Article 8 claim. The decision maker must consider whether removal interferes with private or family life; if so, does the interference reach the Article 8 threshold? If so, is it in accordance with the law? If so, is it necessary in the interests of national security, public safety, economic well-being, health, and morals? And if so, is it proportionate to the legitimate, desired public end? These are the criteria which underpin the so-called proportionality principle.

When the HRA was introduced, a very conservative Immigration Tribunal (the upper tier in the immigration courts) appeared, together with the Court of Appeal, to close ranks in an attempt to mitigate its potentially radical impact. Alongside them stood the House of Lords, not yet 
the corrective it would become later in the decade. Vis-àvis Article 8, the courts' position was that a case had to be exceptional for it to succeed. Furthermore, the Immigration Tribunal was considered to be the principal fact finder and the higher courts would only interfere if a decision was seen to be perverse and/or fell without an acceptable margin of discretion. In 2000, the Court of Appeal, in the case of Mahmood, ${ }^{8}$ heavily influenced by the European Court of Human Rights, set down guidelines as to the correct approach to be taken by decision makers seeking to strike a fair balance between the claims of family life against the need to uphold the integrity of immigration control. Essentially, removal of one family member from a State where other family members were lawfully resident would not infringe Article 8 provided that there were no insurmountable obstacles to the family living together in the Appellant's country of origin, even where they would experience a degree of hardship.

The Court placed much emphasis on the negative aspects of Article 8 cases, such as the inherent weakness of an Article 8 application where enforcement action predated a marriage and the parties entered into the marriage fully aware of the Appellant's tenuous immigration status. Moreover, it was solely the impact on the Appellant's human rights and not those of the family that the Court was obligated to consider.

By 2007 though, the prevailing wind had at last turned in favour of the individual. The House of Lords was in a liberal phase and set down a series of landmark Article 8 cases, most notably in the cases of Huang, ${ }^{9}$ Beoku-Betts, ${ }^{10}$ and Chikwamba. ${ }^{11}$

In Huang, the exceptionality test was dispensed with, as was the margin of discretion-or appreciation-principle. The Court found that it was incumbent upon the Tribunal to determine whether an immigration decision was incompatible with the Human Rights Convention and therefore unlawful. Simply reviewing the decision of the primary decision maker would not suffice. The Court emphasized "the core value" which Article 8 exists to protect, namely, the family. It went on to articulate all of the factors that were important in determining the strength of a family unit, such as financial and emotional dependence, cultural traditions, and its closeness and previous history.

In overturning the Court of Appeal decision in BeokuBetts, the Lords found that the correct approach in Article 8 cases was to have regard to the family unit as a whole and to the impact of removal of the Appellant upon each and every one of the family members. This constituted an important departure from previous precedent that had focused almost exclusively on the Appellant. Baroness Hale of Richmond summarized the Court's approach, as follows:
To insist that an appeal to the Asylum and Immigration Tribunal consider only the effect upon other family members as it affects the appellant, and that a judicial review brought by other family members considers only the effect upon the appellant as it affects them, is not only artificial and impracticable. It also risks missing the central point about family life, which is that the whole is greater than the sum of its individual parts. The right to respect for the family life of one necessarily encompasses the right to respect for the family life of others, normally a spouse or minor children, with whom that family life is enjoyed.

In Chikwamba, the thorny issue of Home Office delay in dealing with cases was addressed. The Lords held that delay in the decision-making process could result in an applicant developing closer personal and social ties and deeper roots in the host community, thereby strengthening an Article 8 claim. Moreover, the longer the passage of time without a decision, the less force the proportionality argument that a relationship, however genuine, is trumped by immigration irregularities, will have. Finally, the more dysfunctional, inconsistent, and unfair the system as a whole is shown to be, the more the weight of the integrity of immigration control argument is reduced.

For the first time, the Home Office was to be held to account on the delay issue. Whilst it would not eliminate the entrenched problem of the limbo status of thousands of asylum seekers, the hope was that it would at least exercise government minds and start to make some inroads.

The private life plank of Article 8 has proved to be much more intractable. Interference with a person's "physical or moral integrity," as the courts have termed it, has been very hard to prove. However, in Razgar, the House of Lords accepted the proposition that the detrimental effect of removal on a person's mental health might well engage Article 8. The Court held that the Appellant, an Iraqi Kurd, had a right to a substantive human rights appeal on the basis of his human rights under Article 8 of the ECHR. The Appellant faced removal to Germany where his asylum claim had been refused and where he alleged he had been subjected to racist abuse. The Home Office maintained that the Appellant's human rights claim was manifestly unfounded but the Lords found that due to the adverse state of his mental health, his rights under Article 8 could be engaged even if his removal did not violate Article 3 . The Appellant had previously attempted suicide and been diagnosed as suffering with depression and post-traumatic stress disorder. $\mathrm{He}$ was on medication and undergoing psychiatric therapy in the UK. He argued that he would be deprived of the equivalent treatment in Germany. The Court concurred with the findings of the European Court in Bensaid 12 that the Appellant's mental health "must also 
be regarded as a crucial part of private life associated with the aspect of moral integrity ... The preservation of mental stability is in that context an indispensible precondition to effective enjoyment of the right to respect for private life."

As regards Article 3 of the ECHR, two major factors have ensured that the advent of the HRA has not acted as a catalyst for the courts' interpretation of it to develop in the broad manner that has taken place with Article 8.

Firstly, there is the fact that Article 3 of the ECHR is an unqualified right and can never be subjected to the kind of balancing act that occurs in the case of the Article 8 proportionality test. No exception or derogation from Article 3 is possible, even in circumstances where a public emergency threatens the life of the nation. And secondly, the predominance of health cases within the ambit of Article 3 has consistently politicized it and, de facto, rendered it a "floodgates" issue. In other words, the powers that be have been exceptionally wary of setting a favourable precedent that could lead to a multitude of successful claims by so-called health tourists or others suffering from life-threatening illnesses. Whereas in Article 8 claims, the presumption is that Applicants may well end up contributing to British society, with Article 3, it is believed they will only ever be a burden.

The issue of HIV-AIDS is the defining one as far as Article 3 is concerned. Ironically, prior to the HRA, the Home Office policy on HIV was more liberal than the decisions emanating from Strasbourg. The 2007 decision of the European Court in $D^{13}$ set down firm principles which would make it almost impossible for someone to win an Article 3 case on health grounds. It was held that the expelling state is not obligated to provide medical care indefinitely to those who would be unable to access an equivalent level of treatment in their own country. Even if the returnee's life expectancy was to be significantly reduced, barring very exceptional circumstances, it would not be enough to breach Article 3 . D only won his case because he was very close to dying of AIDS and had no possibility of medical treatment or family support in his country of origin, St. Kitts.

In another landmark case, namely that of $N,{ }^{14}$ the Appellant argued that his AIDS-related illness was being controlled by the combination therapy (anti-retroviral drugs) he was receiving in the UK and that, were he to be returned to Uganda, the limited nature of the treatment and drugs available there would result in his rapid and fatal deterioration. Combination therapy is very tricky to administer and cannot easily be varied in the way that antibiotics can. The House of Lords rejected his case and the European Court did likewise.

Until recently, almost exclusively the only cases which deal with the core asylum issues have been successful in terms of Article 3. Interestingly though, there have been signs of a judicial thaw emanating from the impenetrable brick wall of $D$ and $N$. In the case of $J A,{ }^{15}$ the Court of Appeal found in favour of an HIV-positive Appellant from the Ivory Coast who had been diagnosed after arriving in the UK and was receiving anti-retroviral drugs from the National Health Service (NHS). Her case was distinguishable from $D$ and $N$ on account of the fact that she had entered the country lawfully, had been granted Leave to Remain on the basis of her medical condition (renewal of that Leave was refused after Home Office policy changed), and had been lawfully resident in the UK for some nine years. She did not therefore need to demonstrate exceptional circumstances. However, it ought to be stressed that the Court of Appeal only allowed the appeal to the extent that it remitted it back to the Asylum and Immigration Tribunal to be heard anew.

The real thorn in the side of the Home Office is the question of alleged terrorists who cannot be excluded in breach of Article 3. Much to its chagrin, the government has consistently been thwarted by the judiciary on a whole raft of socalled national security cases. Of course, this is the principal area in which opponents of the HRA dismiss it as being a liberal tool which protects criminals and terrorists.

It was, arguably, inevitable that there would be a protracted period of percolation whilst the judiciary weighed up the potentially huge ramifications of the HRA. Eventually, the highest court in the land began to lead from the front and adopt a more expansive position. Meanwhile, the Court of Appeal, still displaying its trademark conservatism and, notwithstanding the odd enlightened decision, as in the case of $J A$ mentioned above, stubbornly refuses to soften its stance.

In the case of TM, KM and $L Z,{ }^{16}$ three Zimbabweans, the Court of Appeal placed negligible weight upon low-level surplace activity (a person becomes a "refugee sur-place" either as a result of circumstances arising in his country during his absence or due to his own actions, such as expressing his political views in the country where he has sought refuge). Furthermore, it called into question whether the principles set down by the Supreme Court (see below) in $H J$ and $H T,{ }^{17}$ that gays should not be expected to lie about their sexuality upon return to their home country, could properly be transposed onto the issue of an Appellant's political opinion. Whilst the principle enunciated in HJ and HT does theoretically apply to all Convention grounds, Elias J. expressed doubt that it would be as far-reaching as the Zimbabwean Appellants had sought to argue. The matter would need to be explored at a later date but it would likely revolve around whether the proposed action giving rise to persecution was at the core of a human right or at its margins. 


\section{Asylum Welfare}

The issue of the welfare of asylum seekers and the denial of their right to work has been always been a vexatious one. Successive governments have been guided by the principle of deterrent, believing that asylum seekers come to the UK because they see it as a soft touch, especially in respect of welfare provision. The Labour government steadily ratcheted up the restrictions that were already in place under the previous regime. Whereas the Tories had denied benefits to asylum seekers who failed to apply for asylum at the port of entry and all those whose applications were refused, Labour went further in withdrawing them from all asylum seekers. With regard to their right to work, the Tory policy had been to allow asylum seekers to apply for a work permit six months after lodging their application if no decision had been made (this was automatically withdrawn if they were refused). In 2002, Labour introduced a blanket ban on their right to work, although this was softened a little in 2005, when it was decided that they could work if they had been waiting twelve months for a decision on their claim. In 2010, the Supreme Court held that the twelve-month rule also applied to refused asylum seekers who lodged a "fresh claim."18

Tory legislation denying benefits to certain categories of asylum seekers was challenged successfully in the courts. In 1996, the High Court found that Section 21 of the 1948 National Assistance Act, originally designed to provide residential accommodation to those in need of care and attention, could also apply to destitute asylum seekers who needed Local Authorities to care for them to prevent them from literally starving to death. ${ }^{19}$ In response, Local Authorities in London began to disperse asylum seekers to other parts of the country. Labour embraced dispersal and formalized it in its Immigration and Asylum Act 1999. The nightmare scenarios for both central and local government were avoided. For the former, the spectacle of thousands of asylum seekers on the streets of London was avoided, and for the latter, the lack of geographical restrictions averted a potentially serious accommodation crisis in the capital.

Nonetheless, dispersal caused a great amount of hardship and hurt. Families and communities were split up as thousands of asylum seekers were shipped off to run-down sink estates in cities and far-flung corners of rural England where many of the inhabitants had never come into contact with black or ethnic minority people. The government failed to consult and make adequate provision for local authorities to cope with the increased strain on services. Inevitably, this caused a great deal of resentment and social division.

The National Asylum Support Service (NASS) was the body charged with administering the system and major asylum charities, such as the Refugee Council, happily collaborated with it. A lot of money was made as uninhabitable buildings were shoddily spruced up to accommodate asylum seekers, not least by disreputable landlords who did deals with NASS at excessive rents. Lawyers brought cases to try and keep their vulnerable clients (particularly those who had been dispersed but then fled back to London after being racially abused in the dispersal area) in London where their community and support networks were. Most challenges were rejected by the courts. The Court of Appeal tinkered with the Section 21 judgment but essentially came to the same conclusion.

The 1999 Act also introduced a controversial system of food vouchers for asylum seekers. Not only was the amount less than the level of income support, it was also limited to certain supermarkets and did not allow for any change in the form of cash in the event that the items purchased were less than the value of the voucher. Asylum seekers were duly humiliated as they were often forced to walk miles to the designated supermarket and were clearly identifiable as they produced their vouchers at the checkout. The system was scrapped in 2002.

The Nationality Immigration and Asylum Act of 2002 was introduced by the Labour government. Section 55 of that act denied asylum seekers any means of support from the government unless they had claimed asylum "as soon as was reasonably practicable" after arriving in the country. Despite the government claiming, during the passage of the bill, that Section 55 would only target people who had been in the country for some time and who claimed asylum at the last minute to avoid removal, in practice as many as 90 per cent of asylum seekers fell foul of this provision. The inevitable legal challenge to the government in 2003 was successful. The High Court ruled, in the case of $Q$ and others, that the way it was operating the policy, effectively rendering the vast majority of asylum seekers totally destitute, breached the UK's obligations under Article 3 of the ECHR. ${ }^{20}$

The Secretary of State appealed the decision in $Q$ and, although the Court of Appeal upheld the Administrative Court's findings on Article 3, it watered them down somewhat in holding that Applicants needed to show that they had made serious efforts to find accommodation.

In the 2005 case of Limbuela, the House of Lords set down further guidance on the issue of Article 3 and destitution. It upheld the Court of Appeal's findings in $Q$ as regards the Article 3 breach but, in view of the scarcity of accommodation, held that there was no requirement for asylum seekers to demonstrate that they had looked for it. ${ }^{21}$

In 2008, the House of Lords ruled that the High Court judgment in $M$ was wrong and that being able-bodied but destitute was not enough to qualify for Local Authority care under Section 21 of the National Assistance Act. ${ }^{22}$ 
In 2009, the issue of unaccompanied child asylum seekers, known as unaccompanied minors, was litigated. Where such minors present themselves to a Local Authority with no accommodation, they will necessarily be accommodated under Section 20 of the Children Act 1989 until they are eighteen, when the Local Authority will continue to support them under what are known as the Leaving Care provisions of the Children Act. The responsibility to support minors, often until they reach twenty-four, is an onerous and costly one, which is why Local Authorities routinely would claim to have supported child asylum seekers under an alternative provision of the Children Act (Section 17) so as to avoid the need to help them once they turned eighteen. Whilst the High Court and the Court of Appeal dismissed, in a major test case, a challenge to the way Local Authorities avoided their Leaving Care responsibilities, the House of Lords allowed an appeal, deciding in a ground-breaking judgment that virtually all minors accommodated by Local Authorities were deemed to have been housed under Section 20 of the Children Act. ${ }^{23}$

In another ground-breaking judgment involving unaccompanied minors, the Supreme Court ruled (again overturning the Court of Appeal) that the contentious issue of unaccompanied minors' true ages-they were, and still are, often accused of mendacity when claiming to be under eighteenshould be decided ultimately by the courts on the balance of probabilities rather than by way of a conventional Judicial Review challenge requiring the claimant to show that the Local Authority had acted perversely, a much harder hurdle to overcome. ${ }^{24}$

\section{The Supreme Court}

The new Supreme Court replaced the House of Lords in October 2009. Its introduction was essentially a matter of propriety, as it was designed to bring increased clarity and modernity to the separation of powers between the legislature and the judiciary. It has continued to set down liberal judgments. One example from 2010 dealt with the issue of homosexuals. The Supreme Court overturned a Court of Appeal judgment in the case of HJ and HT in which it was held that homosexuals could reasonably be expected to conceal their sexuality in their home country, in order to avoid persecution. It gave short shrift to this argument when it declared that compelling a gay person to pretend that his sexuality does not exist is to deny him the right to be who he is.

\section{The Safe Third Country Principle}

The return of asylum seekers to so-called safe third countries, such as the US, Canada, Switzerland, or European Union (EU) member States, has been troublesome to administer and often unjust. The Dublin Convention of 1997, part of the EU harmonization program, introduced the principle that individuals must make their asylum application in the first EU country they enter. They can be returned to another EU member State if it is found that they either passed through that State or lodged a claim there. One of the motivations behind the Convention was to put an end to what has been called "asylum shopping," the idea that asylum seekers willfully decide where they will claim asylum depending on the level of welfare benefits and reception conditions.

As well as creating another level of bureaucracy, being a drain on resources, and preventing the reunification of families, the Convention has resulted in asylum seekers being returned to countries which accept them under sufferance and who, particularly in the cases of Greece and Italy, do not provide them with treatment befitting so-called mature democracies that are signatories to the Geneva Convention. Indeed, in 2008, sixty-three refugee-assisting organizations urged all EU countries to cease removals to Greece under the Dublin Convention (Norway and Finland both did so) and an open letter to EU governments from the European Council on Refugees and Exiles (ECRE) referred to the lack of a fair determination procedure in Greece and risk of serious human rights violations there. The Greek policy of detaining asylum seekers in metal containers caused outrage in 2005 as did the 2003 Italian policy of shooting at boats carrying illegal immigrants.

The fact is that significant differences still exist in the asylum policies of member States and, throughout the period of the Dublin Convention, there have been grave concerns that asylum seekers returned from the UK to other EU countries might then be expelled back to the country of origin where a real risk of persecution exists. Consequently, many hundreds of third-country cases have been heard both by the UK courts and the European Court of Human Rights.

In 1999, in the landmark case of Dahmas, ${ }^{25}$ the Court of Appeal ruled that Denmark was not a safe country for the Appellant, an Algerian political activist, to be sent back to. He had already had his asylum claim rejected by the Danish authorities and faced the prospect of being summarily removed back to Algeria. The judgment articulated two vitally important principles: firstly, that whilst in general it is not within the remit of the UK to second-guess or to scrutinize the decisions of other European tribunals, in cases where the facts are so startling, and where the decision of another has been so perverse and manifestly irrational, it is incumbent upon the courts to quash it; and secondly, that in cases where there is every likelihood that someone will be returned to a country where they will face persecution in the form of detention and torture, decision makers must have ultimate recourse to the 1951 Convention and its 
obligations with regard thereto; i.e. the protection principle is paramount.

Notwithstanding Dahmas, it has been immensely difficult to stem the tide of third country removals. In 2008, the European Court upheld a decision of the Court of Appeal in the case of KRS26 that the Appellant, an Iranian national, could be returned from the UK to Greece and, in the case of Nasseri ${ }^{27}$ in 2009, the House of Lords concurred with the Court of Appeal that the Appellant, an Afghan national, could also be returned from the UK to Greece. Both Appellants had been refused asylum in Greece and argued that they would be refouled to their native countries in breach of Article 3. In both cases, it was held that no evidence existed that Greece returned asylum seekers to Iran and Afghanistan. It was open to the Appellants to apply to the European Court for a Rule 39 indication ${ }^{28}$ against Greece once they were back in that country.

\section{Accreditation}

In 2007, in order to ensure that legal advice met the highest of standards-the sector has long been blighted by disreputable lawyers and so-called consultants-the government introduced an accreditation scheme for everyone providing publicly funded immigration services. There is certainly a feeling amongst immigration lawyers that they have been singled out by government. Indeed, no other area of the law has had an accreditation requirement imposed upon it. Moreover, many experienced lawyers I have spoken to do not believe that accreditation has been particularly efficacious. They point out that it does not appear to have curtailed unscrupulous legal aid practitioners, as after all, shoddy work is more a result of negligence than it is of ignorance. There is also a strong feeling that the scheme ought to have been extended to the private, i.e. non-legal aid, sector.

\section{The Backlog-Amnesty Issue}

By 2000, it was reported that there was a backlog of some 100,000 undecided asylum applications. This was believed to have risen to a staggering 450,000 cases by 2006 . For at least twenty years, both Tory and Labour governments, whilst refusing to utter the politically sensitive word "amnesty," have engaged in backlog reduction by administrative means. The tools at their disposal have included significant increases in discretionary grants of ELR, concessionary "statue of limitation" policies such as the fourteen-year rule which allows those who have been living in the UK illegally for fourteen years to remain indefinitely, and other oneoff initiatives. For example, in 1998, Labour allowed up to 30,000 asylum seekers who had been waiting several years for a decision on their applications to stay and, in 2003, it allowed 15,000 families who had waited more than three years for a decision to remain.

In 2008, the government announced that it had considered around a third of the 450,000 so-called "legacy" cases and had awarded some 40 per cent of them Leave to Remain. The right-wing press and conservative pressure groups rail against the grant of unjustified amnesty whilst politicians with a more enlightened view, such as the coalition government's deputy prime minister, Nick Clegg, talk about a route to citizenship for those who have been resident in the UK for ten years. London mayor Boris Johnson has even advocated a five-year-long residence concession.

\section{Coalition Policies}

The Conservative-Liberal Democrat coalition government has pledged to introduce a cap on the number of non-EU economic migrants permitted to live and work in the UK, particularly skilled workers and students. It has also promised to crack down on illegal immigration and trafficking by setting up a Border Police Force. The Prime Minister continues to emphasize his desire to reduce annual net migration levels. As far as asylum is concerned, the government has pledged to look at ways of speeding up the system and making it more cost-effective. It has also introduced a new process to enforce the removal of families who have been refused permission to stay in the UK.

With regard to funding, in November 2010, Ken Clarke set out his proposals for what the Guardian newspaper has referred to as the most drastic cuts to legal aid in its sixtyyear history. Routine immigration matters such as entry clearance applications and the grant or variation of Leave to Remain will no longer be funded, neither will advice on asylum welfare matters, and lawyers will have their fees reduced by 10 per cent.

\section{Statistics: Applications and Decisions}

In 2000 , the UK received a record 76,040 asylum applications. In terms of decisions made in that year, 10 per cent of applicants were granted Refugee Status and a further 12 per cent were granted ELR. By 2009, the number of applications had fallen significantly to 24,250 . Decision-wise, 27 per cent of applicants were allowed to remain in the UK.

This century, Europe-wide, the UK has tended to be ranked in and around tenth position in terms of the number of asylum seekers it has in relation to its population. However, in relation to France, Germany, and Italy, the three other countries with the largest populations, the UK has a higher figure, both in absolute and per capita terms. 


\section{Conclusion}

In conclusion, it appears to be very much a case of "plus ca change c'est la même chose" under the Conservative-Liberal Democrat coalition government: more cuts, more detention, more deportations, more poor quality Home Office decision making, more lawyers forced out of the sector, and less access to justice for asylum seekers and other immigrants. The principal counterweight to this continued dogmatism on the part of government remains the enlightened minds within the upper echelons of the British judiciary.

\section{Notes}

1. Wystan H. Auden, "Museé des Beaux Arts," in Another Time (1940); quoted from: Political Analysis from the Inside, Harvey Burgess (Oxford: Worldview Publications, 2001), 1.

2. Harvey Burgess, Political Asylum from the Inside (Oxford: Worldview Publications, 2001), 162.

3. Ibid., 119.

4. Paul Lewis, Matthew Taylor, and Cecile de Comarmond, "Man Who Died on Deportation Flight Was 'Heavily Restrained,' " The Guardian (October 15, 2010), 2.

5. Billy Kenber, "Guards Deporting Migrants Are Allowed to Use Restraint Methods That Can Kill," The Times (October 28, 2010), 5 .

6. Lewis, Taylor, and de Comarmond, "The Man Who Died on Deportation," 5.

7. Razgar v. Secretary of State for the Home Department, [2004] UKHL 27.

8. Mahmood v. Secretary of State for the Home Department, [2001] 1 WLR 840.

9. Huang v. Secretary of State for the Home Department [2007] UKHL 11.

10. Beoku-Betts v. Secretary of State for the Home Department [2008] UKHL 39.

11. Chikwamba v. Secretary of State for the Home Department [2008] UKHL 40.

12. Bensaid v. United Kingdom [2001] 33 EHRR 2050.

13. D v. United Kingdom [2007] 30240/96.

14. N v. Secretary of State for the Home Department [2005] UKHL 31; Nv. United Kingdom [2008 ] 26505/05.
15. JA and ES v. Secretary of State for the Home Department [2009] EWCA Civ 1353.

16. TM, KM and LZ v. Secretary of State for the Home Department [2010] EWCA Civ 916.

17. HJ and HT v. Secretary of State for the Home Department [2010] UKSC 31.

18. ZO and others v. Secretary of State for the Home Department [2010] UKSC 36.

19. $R v$. London Borough of Hammersmith and Fulham ex parte $M$ [1997] 30 HLR 10.

20. $Q$ and others v. Secretary of State for the Home Department [2003] EWHC 195 (admin).

21. Limbuela and others v. Secretary of State for the Home Department [2005] UKHL 66.

22. $R$ (On the application of $M)(F c) v$. Slough Borough Council [2008] UKHL 52.

23. $R$ (On the application of $G$ ) v. Southwark LBC [2009] 1WLR34.

24. $R$ (On the application of A) v. Croydon LBC [2009] 1WLR2557.

25. $R v$. Secretary of State for the Home Department, ex parte Dahmas - [1999] All ER (D) 1280.

26. European Court of Human Rights. KRS v. United Kingdom Application no. 32733/08.

27. Nasseri v. Secretary of State for the Home Department [2009] UKHL 23.

28. Rule 39 of the Rules of the European Court of Human Rights empowers the Court to indicate binding measures to member states to prevent, until further notice, the imminent expulsion or extradition of failed asylum seekers or irregular migrants at risk of harm of a serious, irreparable nature in their country of origin. In 2008, the Court dealt with over 3,000 such requests.

Harvey Burgess, a British immigration legal practitioner, is the author of Political Asylum from the Inside (Oxford: Worldview Publications, 2001). He is affiliated to London based lawyers, Elder Rahimi and Clore \& Co.

(C) Harvey Burgess, 2010. This open-access work is licensed under a Creative Commons Attribution-NonCommercial 4.0 International License, which permits use, reproduction and distribution in any medium for non-commercial purposes, provided the original author(s) are credited and the original publication in Refuge: Canada's Journal on Refugees is cited. 